\title{
Pengaruh Senam Hamil Terhadap Lama Persalinan di Klinik Bersalin Budi Mulia Medika Palembang
}

\author{
Juliana Widyastuti Wahyuningsih ${ }^{1}$, Dela Marsela2 \\ Akademi Kebidanan Budi Mulia Palembang ${ }^{1,2}$
}

Informasi Artikel :

Diterima : 02 November 2021

Direvisi : 09 November 2021

Disetujui : 20 Desember 2021

Diterbitkan : 30 Desember 2021

*Korespondensi Penulis : yuliana_widyastuti@ymail.com

\section{A B S T R A K}

Senam atau latihan selama kehamilan memberikan dampak positif terhadap pembukaan serviks dan aktifitas uterus yang terkoordinasi saat persalinan, ditemukan juga secara bermakna persalinan yang lebih awal dan lama persalinan yang lehih singkat dibandingkan dengan tidak melakukan senam hamil. Senam hamil dapat membantu persalinan sehingga ibu dapat melahirkan tanpa kesulitan. Tujuan dari penelitian ini adalah untuk mengetahui pengaruh senam hamil terhadap lama persalinan di Klinik Bersalin Budi Mulia Medika Palembang. Penelitian ini menggunakan metode survey comparative study (studi perbandingan) dengan pendekatan cross sectional (potong lintang). Populasi dalam penelitian ini adalah semua ibu bersalin dengan persalinan normal spontan di Klinik Bersalin Budi Mulia Medika yang berjumlah 277 orang. Sampel dalam penelitian adalah ibu dengan persalinan normal spontan yang dibagi menjadi dua kelompok yaitu terdiri dari 54 ibu bersalin yang melakukan senam hamildan $54 \mathrm{ibu}$ bersalin yang tidak melakukan senam hamil. Dari hasil penelitian yang telah dilakukan tentang hubungan senam hamil dengan lama Persalinan di Klinik Bersalin Budi Mulia Medika Palembang terdapat 108 sampel yang dapat diambil kesimpulan Terdapat pengaruh senam hamil terhadap lama Persalinan Kala I pada ibu bersalin yang melakukan senam hamil dan yang tidak melakukan senam hamil. Terdapat pengaruh senam hamil terhadap lama Persalinan Kala II pada ibu bersalin yang melakukan senam hamil dan yang tidak melakukan senam hamil.

\section{Kata Kunci : Senam Hamil, Lama persalinan.}

\section{ABSTRACT}

Gymnastics or exercise during pregnancy has a positive impact on cervical dilatation and coordinated uterine activity during labor. Pregnancy exercise can help with labor so that the mother can give birth without difficulty. The purpose of this study was to determine the effect of pregnancy exercise on the length of labor at the Budi Mulia Medika Maternity Clinic in Palembang. This study uses a comparative survey study method (comparative study) with a cross sectional approach (cross-sectional). The population in this study were all mothers who gave birth spontaneously at the Budi Mulia Medika Maternity Clinic, which sold 277 people. The sample in this study were mothers with normal delivery who were divided into two groups, consisting of 54 women who gave birth who did pregnancy exercise and 54 women who did not do pregnancy exercise. From the results of research that has been carried out on the relationship between pregnancy exercise and labor duration at the Budi Mulia Medika Maternity Clinic, Palembang, there are 108 samples that can be concluded. There is an effect of pregnancy exercise on the duration of the second stage of labor in maternity women who do pregnant exercise and who do not do pregnancy exercise.

Keywords: Pregnancy Exercise, Length of labor 


\section{PENDAHULUAN}

Kehamilan merupakan masa yang dimulai dari konsepsi sampai lahirnya janin. Lamanya hamil normal adalah 280 hari (40 minggu atau 9 bulan 7 hari). Kehamilan ini dibagi atas 3 semester yaitu; kehamilan trimester pertama mulai 0-14 minggu, kehamilan trimester kedua mulai mulai 14-28 minggu, dan kehamilan trimester ketiga mulai 28-42 minggu (Yuli, 2017).

Persalinan adalah suatu proses dimana seorang wanita melahirkan bayi yang diawali dengan kontraksi uterus yang teratur dan memuncak pada saat pengeluaran bayi sampai dengan pengeluaran plasenta dan selaputnya dimana proses persalinan ini akan berlangsung selama 12 sampai 14 jam (Kurniarum, 2016).

Menurut data World Health Organization (WHO), angka kematian ibu di dunia pada tahun 2015 adalah 216 per 100.000 kelahiran hidup atau diperkirakan jumlah kematian ibu adalah 303.000 kematian dengan jumlah tertinggi berada di negara berkembang yaitu sebesar 302.000 kematian.

Angka Kematian Ibu di Indonesia termasuk tinggi diantara negara-negara ASEAN. Berdasarkan Survei Demografi dan Kesehatan Indonesia (SDKI) tahun 2012, angka kematian ibu di Indonesia masih tinggi sebesar 359 per 100.000 kelahiran hidup. Data ini merupakan acuan untuk mencapai target AKI sesuai Sustainable Development Goals yaitu 70 per 100.000 kelahiran hidup pada tahun 2030 (Kemenkes,2015). Kematian ibu di Indonesia tahun 2013 masih didominasi oleh tiga penyebab utama kematian yaitu perdarahan sebesar $30,13 \%$, hipertensi dalam kehamilan sebesar 27,1\%, dan infeksi sebesar 7,3\%. Partus lama juga salah satu penyebab kematian ibu di Indonesia yang angka kejadiannya terus meningkat yaitu $1 \%$ pada tahun 2010, 1,1\% pada tahun 2011, dan 1,8\% pada tahun 2012. (Kemenkes RI, 2016).

Senam atau latihan selama kehamilan memberikan dampak positif terhadap pembukaan serviks dan aktifitas uterus yang terkoordinasi saat persalinan, ditemukan juga secara bermakna persalinan yang lebih awal dan lama persalinan yang lehih singkat dibandingkan dengan tidak melakukan senam hamil. Senam hamil dapat membantu persalinan sehingga ibu dapat melahirkan tanpa kesulitan (Ida dalam Nur, 2016).

Berdasarkan hasil penelitian dari Juita Tahun 2017 tentang "Pengaruh Senam Hamil dengan Lamanya Persalinan Kala I dan Kala II di Bidan Praktik Mandiri (BPM) Dince Safrina Pekanbaru Tahun 2017" ada pengaruh senam hamil dengan lamanya persalinan kala I dan Kala II dengan besar $p$ value 0.005 pada kala I dan 0.002 pada kala II.

Penelitian yang dilakukan oleh Wulandari Tahun 2018 menyatakan bahwa efektivitas senam hamil sebagai pelayanan prenatal dalam menurunkan kecemasan menghadapi persalinan bertujuan untuk membuktikan apakah senam hamil sebagai pelayanan prenatal efektif dalam menurunkan kecemasan menghadapi persalinan pertama. Dari penelitian yang dilakukan didapatkan hasil bahwa ibu hamil yang melakukan senam hamil akan mengalami penurunan kecemasan dalam menghadapi persalinan pertamanya, bila dibandingkan dengan mereka yang tidak melakukan senam hamil.

Menurut Kennelly dan Caffrey (2002) menyatakan bahwa sebagian wanita yang melakukan senam selama kehamilannya, bersalin saat usia kehamilannya 281,8 hari (sekitar 40 minggu), serta sedikit yang memperoleh tindakan medis (seperti penggunaan oksitosin, persalinan dengan forsep, dan seksio sesaria) dan lebih dari 85 $\%$ persalinannya pervaginam tanpa kompikasi serta lamanya persalinannya lebih singkat (Muhimah, 2010)

Berdasarkan data dari Klinik Bersalin Budi Mulia Medika Palembang, ibu bersalin yang memperoleh tindakan medis seperti penggunaan oksitosin, persalinan dengan 
tindakan terutama seksio sesaria rata- rata karena adanya komplikasi persalinan dan tidak adanya kemajuan persalinan atau Kala II lama. Hal ini merupakan salah satu masalah yang sering terjadi pada ibu bersalin serta masih rendahnya kunjungan senam hamil yaitu hanya $45 \%$ dalam 1 tahun di Klinik Bersalin Budi Mulia Medika . Berdasarkan permasalahan tersebut, penulis tertarik untuk melakukan penelitian tentang Pengaruh Senam Hamil terhadap Lama Persalinan di. Klinik Bersalin Budi Mulia Medika

\section{METODE PENELITIAN}

Penelitian ini menggunakan metode survey comparative study (studi perbandingan) dengan pendekatan cross sectional (potong lintang). Populasi dalam penelitian ini adalah semua ibu bersalin dengan persalinan normal spontan di Klinik Bersalin Budi Mulia Medika yang berjumlah 277 orang. Sampel dalam penelitian adalah ibu dengan persalinan normal spontan yang dibagi menjadi dua kelompok yaitu terdiri dari 54 ibu bersalin yang melakukan senam hamildan 54 ibu bersalin yang tidak melakukan senam hamil.

Analisis univariat adalah untuk melihat distribusi frekuensi dan persentase dari tiap variiabel yang diteliti. Analisis bivariat dilakukan dengan menggunakan Uji Chi Kuadrat dan Uji $t$ test untuk mengetahui hubungan dan perbandingan pengaruh antara variabel bebas (senam hamil) dengan variabel terikat (lama persalinan).

\section{HASIL PENELITIAN}

\section{Analisis Univariat}

Analisis ini untuk melihat gambaran karakteristik atau ciri responden menurut masing- masing variabel penelitian, dimana Variabel bebas (senam hamil) sedangkan variabel terikat (Lama persalinan). Tujuan dari pembuatan distribusi frekuensi adalah untuk mengenali besaran dari suatu fenomena yang dilihat menurut karakter yang digunakan. Hasil Univariat dapat dilihat dari tabel berikut ini :

a. Distribusi Proporsi Senam Hamil di Klinik Bersalin Budi Mulia Medika

Tabel 1 Distribusi Proporsi Responden
Berdasarkan Senam Hamil di
Klinik Bersalin Budi Mulia
Medika

\begin{tabular}{clcc}
\hline No & Senam Hamil & Jumlah & Persentase(\%) \\
\hline 1. & Senam Hamil & 54 & 50.0 \\
\hline 2. & $\begin{array}{l}\text { Tidak Senam } \\
\text { hamil }\end{array}$ & 54 & 50.0 \\
\hline & Total & 108 & 100 \\
\hline
\end{tabular}

Tabel 1 menunjukkan bahwa dari 108 responden dibagi menjadi 2 kelompok dengan jumlah yang sama yaitu kelompok ibu bersalin yang melakukan senam hamil sebanyak 54 orang sedangkan kelompok ibu bersalin yang tidak melakukan senam hamil sebanyak 54 orang.

\section{b. Distribusi Proporsi Lama Persalinan Kala I di Klinik Budi Mulia Medika}

\section{Tabel 2 Distribusi Proporsi Responden Berdasarkan Lama Persalinan di Klinik Bersalin Budi Mulia Medika}

\begin{tabular}{clcc}
\hline No & $\begin{array}{l}\text { Lama } \\
\text { Persalinan }\end{array}$ & Jumlah & $\begin{array}{c}\text { Persentase } \\
(\%)\end{array}$ \\
\hline 1. & Normal & 65 & 60,2 \\
\hline 2. & Tidak Normal & 43 & 39,8 \\
\hline & Total & 108 & 100 \\
\hline
\end{tabular}

Tabel 2 menunjukkan bahwa responden dengan lama Persalinan Kala I normal sebesar $60,2 \%$ lebih banyak dibandingkan dengan yang tidak normal yaitu sebesar 39,8\% . 
Jurnal Kebidanan : Jurnal Medical Science Ilmu Kesehatan Akademi Kebidanan Budi Mulia Palembang Volume.11 No.2, Desember 2021

Available online https://journal.budimulia.ac.id/

\section{Analisis Bivariat}

Analisis bivariat untuk mengetahui interaksi dua variabel, baik berupa komparatif, asosiatif maupun kolektif. Analisis ini dilakukan dengan menggunakan Uji $t$ - test untuk mengetahui pengaruh antara variabel bebas (senam hamil) dengan variabel terikat (Lama Persalinan).

\section{a. Pengaruh Senam Hamil Terhadap Lama Persalinan di Klinik Bersalin Budi Mulia Medika Palembang}

Tabel 3 Hubungan antara Senam Hamil Terhadap Lama Persalinan Kala I di Klinik Bersalin Budi Mulia Medika Palembang

\begin{tabular}{|c|c|c|c|c|c|c|c|}
\hline \multirow[t]{2}{*}{ NO } & \multirow{2}{*}{$\begin{array}{c}\text { Ibu } \\
\text { Bersalin }\end{array}$} & \multicolumn{2}{|c|}{ Lama Persalinan Kala I } & \multirow{2}{*}{$\begin{array}{c}\text { Nilai } \\
\text { Rata- rata }\end{array}$} & \multirow{2}{*}{$\begin{array}{c}\text { Standar } \\
\text { deviasi }\end{array}$} & \multirow[t]{2}{*}{ t hitung } & \multirow[t]{2}{*}{ sig } \\
\hline & & Normal & $\begin{array}{c}\text { Tidak } \\
\text { Normal }\end{array}$ & & & & \\
\hline 1. & $\begin{array}{l}\text { Senam } \\
\text { Hamil }\end{array}$ & 51 & 14 & 9.2326 jam & 2.50834 & \multirow[b]{2}{*}{9.169} & \multirow[b]{2}{*}{0,000} \\
\hline 2. & $\begin{array}{l}\text { Tidak } \\
\text { Senam } \\
\text { Hamil }\end{array}$ & 3 & 40 & $14.2311 \mathrm{jam}$ & 3.12354 & & \\
\hline & Total & 54 & 54 & & & & \\
\hline
\end{tabular}

Dari hasil penelitian didapatkan bahwa pada kelompok ibu bersalin yang melakukan senam hamil, lama Persalinan Kala I normal lebih banyak, dengan nilai rata- rata 9.2326 jam lebih singkat dibandingkan pada kelompok ibu yang tidak melakukan senam hamil. Sedangkan pada kelompok ibu bersalin yang tidak melakukan senam hamil, lama Persalinan Kala I tidak normal lebih banyak, dengan nilai rata- rata 14.2311 jam lebih panjang dibandingkan pada kelompok ibu yang melakukan senam hamil. Berdasarkan dari hasil Uji $t$ - test didapatkan nilai t hitung 9,169 dengan nilai sig. $(0,000)<(0,05)$ yang artinya terdapat pengaruh senam hamil terhadap lama Persalinan Kala I pada kelompok ibu bersalin yang melakukan senam hamil.

\section{b. Pengaruh Senam Hamil dengan Lama Persalinan Kala II di Klinik Bersalin Budi Mulia Medika Palembang}

Tabel 5 Pengaruh Senam Hamil dengan Lama Persalinan Kala II di Klinik Bersalin Budi Mulia Medika Palembang.

\begin{tabular}{|c|c|c|c|c|c|c|c|}
\hline \multirow[t]{2}{*}{ No } & \multirow[t]{2}{*}{ Ibu Bersalin } & \multicolumn{2}{|c|}{$\begin{array}{c}\text { Lama Persalinan } \\
\text { Kala II }\end{array}$} & \multirow{2}{*}{$\begin{array}{c}\text { Nilai } \\
\text { Rata- rata }\end{array}$} & \multirow{2}{*}{$\begin{array}{l}\text { Standar } \\
\text { deviasi }\end{array}$} & \multirow[t]{2}{*}{ t hitung } & \multirow[t]{2}{*}{ sig } \\
\hline & & Normal & $\begin{array}{c}\text { Tidak } \\
\text { Normal }\end{array}$ & & & & \\
\hline 1. & Senam Hamil & 54 & 11 & 2.50834 & 0.35155 & & \\
\hline 2. & $\begin{array}{l}\text { Tidak Senam } \\
\text { Hamil }\end{array}$ & 0 & 43 & 2.2315 & 0.87195 & 10.514 & 0,000 \\
\hline & Total & 54 & 54 & & & & \\
\hline
\end{tabular}


Dari hasil penelitian didapatkan bahwa pada kelompok ibu bersalin yang melakukan senam hamil, lama Persalinan Kala II normal lebih banyak, dengan nilai rata- rata 0.8846 jam lebih singkat dibandingkan pada kelompok ibu yang tidak melakukan senam hamil. Sedangkan pada kelompok ibu bersalin yang tidak melakukan senam hamil, lama Persalinan Kala II tidak normal lebih banyak,

\section{PEMBAHASAN}

\section{Pengaruh Senam Hamil terhadap Lama Persalinan Kala I}

Dari hasil penelitian yang dilakukan di Klinik Bersalin Budi Mulia Medika Palembang, dari hasil analisis 108 sampel dibagi menjadi 2 kelompok dengan jumlah yang sama yaitu kelompok ibu bersalin yang melakukan senam hamil yang berjumlah 54 orang $(50,0 \%)$ dan kelompok ibu bersalin yang tidak melakukan senam hamil yang berjumlah 54 orang $(50,0 \%)$. Pada kelompok ibu bersalin yang melakukan senam hamil, lama Persalinan Kala I normal lebih banyak yaitu $(78,5 \%)$, dengan nilai rata- rata 9,2326 jam lebih singkat dibandingkan pada kelompok ibu yang tidak melakukan senam hamil. Sedangkan pada kelompok ibu bersalin yang tidak melakukan senam hamil, lama Persalinan Kala I tidak normal lebih banyak yaitu (93,0 \%), dengan nilai rata- rata 14,2311 jam lebih panjang dibandingkan pada kelompok ibu yang melakukan senam hamil. Berdasarkan dari hasil Uji $t$ - test didapatkan nilai t hitung 9,169 dengan nilai sig. $(0,000)<$ $(0,05)$ yang artinya terdapat hubungan antara senam hamil dengan lama Persalinan Kala I pada kelompok ibu bersalin yang melakukan senam hamil dan kelompok yang tidak melakukan senam hamil.

Pada penelitian ini dapat disimpulkan bahwa lama Persalinan Kala I normal lebih banyak pada kelompok yang melakukan senam hamil sedangkan lama Persalinan Kala I yang tidak normal lebih banyak pada kelompok yang tidak melakukan senam dengan nilai rata- rata 2.2315 jam lebih panjang dibandingkan pada kelompok ibu yang melakukan senam hamil. Berdasarkan dari hasil Uji $t$ - test didapatkan nilai t hitung 10,514 dengan nilai sig. $(0,000)<(0,05)$ yang artinya terdapat pengaruh senam hamil terhadap lama Persalinan Kala II pada kelompok ibu bersalin yang melakukan senam hamil.

hamil. Hal ini sesuai dengan hasil dilapangan dimana rata- rata ibu bersalin yang mengalami lama Persalinan Kala I tidak normal, persalinanya dilakukan dengan tindakan, karena adanya komplikasi persalinan yang menyebabkan tidak adanya kemajuan persalinan. Kemajuan persalinan ditentukan oleh power, pessage, dan pessenger.

Berdasarkan pernyataan diatas diperlukan tindakan pemberian penyuluhan tentang manfaat dari senam hamil kepada para ibu hamil sebagai program asuhan kebidanan, karena senam hamil merupakan salah satu bentuk olah raga yang membantu ibu hamil mendapatkan power yang baik dalam proses persalinan, selain itu olah raga selama kehamilan akan menguntungkan baik fisik maupun fsiologik, mengingat perasaan takut dan cemas dalam menghadapi kehamilan dan persalinan dapat menimbulkan ketegangan jiwa juga fisik, yang dapat menyebabkan kakunya otot- otot persendian sehingga dapat menyebabkan persalinan berjalan tidak wajar.

Menurut Veratamala dan Damar Upahita,2020. Manfaat senam hamil adalah membantu menyediakan energi, Menurunkan resiko komplikasi kehamilan, Membantu mengurangi stres dan membangkitkan suasana hati, Mengurangi ketidaknyamanan saat hamil, Membuat tidur lebih nyenyak, Membantu tubuh mempersiapkan kelahiran, Membantu pemulihan tubuh kebih cepat setelah melahirkan. 
Hasil penelitian ini sesuai dnegan penelitian Luluk Susiloningtyas (2013) yangmengatakan bahwa terdapat hubungan senam hamil dengan kelancaran proses persalinan Kala II pada Primigravida di Wilayah Kerja Puskesmas Wates Kecamatan Kabupaten Kediri. Kesimpylan dari penelitian ini adalah responden melakukan senam hamil mengalami proses kelancaran persalinan Kala II.

\section{Pengaruh Senam Hamil terhadap Lama Persalinan Kala II}

Penelitian ini pada kelompok ibu bersalin yang melakukan senam hamil, lama Persalinan Kala II normal lebih banyak yaitu $(83,1 \%)$, dengan nilai rata- rata 0.8846 jam lebih singkat dibandingkan pada kelompok ibu yang tidak melakukan senam hamil. Sedangkan pada kelompok ibu bersalin yang tidak melakukan senam hamil, lama Persalinan Kala II tidak normal lebih banyak yaitu (100\%), dengan nilai rata- rata 2,2315 jam lebih panjang dibandingkan pada kelompok ibu yang melakukan senam hamil. Berdasarkan dari hasil Uji $t$ - test didapatkan nilai t hitung 10,514 dengan nilai sig. $(0,000)$ $<(0,05)$ yang artinya terdapat hubungan antara senam hamil dengan lama Persalinan Kala II pada kelompok ibu bersalin yang melakukan senam hamil dan kelompok yang tidak melakukan senam hamil.

Berdasarkan hasil penelitian diatas menunjukkan bahwa pada kelompok ibu bersalin yang melakukan senam hamil, lama Persalinan kala II normalnya lebih banyak dan lebih singkat dibandingkan pada kelompok ibu bersalin yang tidak melakukan senam hamil. Hal ini dapat disimpulkan bahwa senam hamil sangat berpengaruh terhadap lama persalinan Kala II.

Senam hamil berperan untuk memperkuat kontraksi dan mempertahankan kelenturan otototot dinding perut, ligament-ligamen, otot-otot dasar panggul dan lain-lain yang menahan tekanan tambahan dan berhubungan dengan persalinan. Senam hamil dapat menyebabkan vaskularisasi dari rahim ke plasenta menjadi lebih baik yang menjamin suplai oksigen dan nutrisi ke janin mencukupi. Latihan -latihan yang dilakukan pada senam hamil tujuan utamanya adalah agar ibu hamil memperoleh kekuatan dan tonus otot yang baik, tehnik pernafasan yang baik, Pada proses persalinan kala II hal yang terpenting adalah power yang persalinan. Pada penelitian menunjukkan bahwa ibu yang mengikuti senam hamil proses persalinan kala II menjadi lebih cepat yaitu $<1$ jam.(Agustiyadi, 2015).

Menurut Dick Read dalam Sulistyawati (2009) bahwa wanita hamil harus mendapat pengertian mengenai proses kehamilan dan persalinan sehingga dapat menghadapi secara realistis dalam artinya hilangnya rasa takut dan cemas. Wanita hamil baru diberi pelatihan teknik relaksasi dan pernafasan untuk mengurangi rasa nyeri dan memperlancar persalinan. Rasa nyeri akan menyebabkan ibu bersalin ijadi stress sehingga akan meningkatkan pengeluaran hormone adrenalin yang menganggusekresi hormone oxytocin pada lobus posterior hipofise sehingga akan menurunkan aktivitasut etrus yang akan memperpanjang waktu persalinan.

Penelitian ini juga sesuai dengan hasil penelitian Oetomo, Sofoewan (1998) di Yogyakarta yang meneliti 100 wanita primigravida didapatkan bahwa kejadian partus lama lebih kecil secara bermakna (1,9 $\%$ vs. $15,1 \%, \mathrm{p}=0,031)$ dikalangan wanita hamil yang melakukan senam hamil, juga lama Persalinan Kala II nya juga secara bermakna lebih singkat dari pada yang tidak melakukan senam hamil. Beberapa literatur mengatakan bahwa wanita yang melakukan senam hamil akan mengalami risiko persalinan lebih kecil dari yang tidak senam dan sedikit yang memperoleh tindakan medis (seperti penggunaan oksitosin, persalinan dengan forcep, dan seksio sesaria) dan lebih 
dari $85 \%$ persalinan pervaginam tanpa komplikasi serta lama peersalinanya lebih singkat.

Kennelly dan Caffrey (2002) menemukan bahwa rata-rata wanita yang melakukan senam selama kehamilannya, bersalin saat usia kehamilannya 281,8 hari (sekitar 40 minggu), serta sedikit yang memperoleh tindakan medis (seperti penggunaan oksitosin, persalinan dengan forsep, dan seksio sesaria) dan lebih dari $85 \%$ persalinannya pervaginam tanpa kompikasi serta lamanya persalinannya lebih singkat (Muhimah, 2010)

Hasil penelitian dari para peneliti diatas dapat dilihat bahwa adanya pengaruh senam hamil terhadap kelancaran persalinan baik itu pisik maupun psikologis, rata- rata ibu yang melakukan senam hamil, lama Persalinan Kala I dan Kala II nya jauh lebih singkat di bandingkan dengan ibu bersalin yang tidak melakukan senam hamil sama sekali, hal ini terlihat dari hasil penelitian yang di lakukan di Klinik Bersalin Budi Mulia Medika Palembang dan hasil dari peneliti lainnya. Berdasarkan hasil penelitian dapat disimpulkan bahwa ada terdapat hubungan antara antara senam hamil dengan lama persalinan Kala I dan Kala II di Klinik Bersalin Budi Mulia Medika Palembang

\section{KESIMPULAN}

Dari hasil penelitian yang telah dilakukan tentang hubungan senam hamil dengan lama Persalinan di Klinik Bersalin Budi Mulia Medika Palembang terdapat 108 sampel yang dapat diambil kesimpulan Terdapat pengaruh senam hamil terhadap lama Persalinan Kala I pada ibu bersalin yang melakukan senam hamil dan yang tidak melakukan senam hamil. Terdapat pengaruh senam hamil terhadap lama Persalinan Kala II pada ibu bersalin yang melakukan senam hamil dan yang tidak melakukan senam hamil.

\section{DAFTAR PUSTAKA}

Agustiyadi, 2015.Hubungan antara Pengetahuan Ibu Hamil dengan Sikap Ibu tentang Senam Hamil di RSU Islam Kustati Surakarta, Tesis. Fakultas Kesehatan

Masyarakat.Universitas Surakarta.

Alimul,Aziz. 2009. Metode Penelitian Kebidanan dan Teknik Analisis Data. Salemba Medika. Jakarta

Azwar, Azrul. 2008. Asuhan Persalinan Normal dan Inisiasi Menyusui Dini. JNPK-KR. Jakarta

Brayshaw E. 2017. Senam Hamil dan Nifas : Pedoman praktis bidan. EGC. Jakarta

Dep. Kes RI, 2009. Profil Kesehatan Indonesia 2008. Jakarta

Dep. Kes. RI, 2007. Standar Pelayanan Kebidanan, Buku 1, Jakarta.

Elfindri, Evi Hasnita, Zainal Abidin, Rizanda Machmud, dan Elmiyasna, 2012. Metodologi Penelitian Kesehatan. Baduose Media. Jakarta.

Hastono, Priyo Susanto. 2008. Statistik Kesehatan. PT RajaGrafindo Persada. Jakarta

Kennelly, Geary, Mc Caffrey, 2002. Related Change In Umbilical And Uterine Artery Waveforms As Assessed by Doppler Ultrasound Scans. AM J Obstet Gynecol

Manuaba, IBG. 2007. Pengantar Kuliah Obstetri. EGC. Jakarta 
Mandriawati, 2008. Panduan Senam Hamil. (http://www.membuatblog.web.id)

Muhimah, N. Safei, 2010. Panduan Lengkap Senam Sehat Khusus Ibu Hamil, cetakan pertama. Jakarta

Nur, Sutaryono dan Sri Lestari. 2016. Hubungan Senam Hamil Terhadap Lamanya Proses Persalinan Pada Ibu Bersalin Diwilayah Kerja Puskesmas Bayat Klaten. Jurnal Involusi Kebidanan Vol. 6 No 11.

Notoatmodjo, Soekidjo. 2002. Metodelogi Penelitian Kesehatan. Rineka Cipta. Jakarta

Pusat Pendidikan Tenaga Kesehatan WHO,JHPIEGO, 2003. Asuhan Ante Natal, Jakarta.

Prawiharjo, Sarwono. 2014. Ilmu Kebidanan. YPB SP. Jakarta

Riduwan. Sunarto, 2007. Pengantar Statistika. Alfabeta. Bandung

Riduwan, 2010. Dasar- dasar Statistika. Alfabeta. Bandung
Saifuddin, Abdul Basri, 2012. Buku Panduan Praktis Pelayanan Kesehatan Maternal dan Neonatal, YBP-SP bekerjasama dengan JN PKKR POGI, Jakarta.

Saryono, 2011. Metodelogi Penelitian Kesehatan. Mitra Cendekia. Yogyakarta.

Siti Hindun, 2011. Pengaruh Senam Hamil terhadap Proses Persalinan di Klinik YK Madira Palembang. Tesis Pascasarjana UNSRI

Sulistyawati, Ari. 2009 Asuhan Kebidanan Pada Masa Kehamilan. Salemba Medika. Jakarta.

SDKI, 2012. Angka Kematian Ibu. (http://www.antara.co.id)

Veratamala dan Damar Upahita,2020.7Manfaat Senam Hamil Selama Kehamilan Hingga Setelah Melahirkan.

https://hellosehat.com/kehamilan/kand ungan/7-manfaat-senam-hamil/.

Warta, 2008. Angka Kematian Ibu di Indonesia Tertinggi di ASEAN. (http://www.waspada.co.id). 
